\title{
Implementation of Failure Mode and Effect Analysis and Fault Tree Analysis in Paper Mill: A Case Study
}

\author{
Nurul Retno Nurwulan ${ }^{1}$, Wilcha Anatasya Veronica ${ }^{2}$ \\ 1,2) Fakultas Teknik dan Teknologi, Jurusan Teknik Industri, Universitas Sampoerna \\ Jl. Raya Pasar Minggu Kav. 46, Jakarta Selatan 12780 \\ E-mail: nurul.nurwulan@sampoernauniversity.ac.id, wilcha.veronica@sampoernauniversity.ac.id
}

\begin{abstract}
A good quality control system is important to be implemented to increase productivity and minimize defects in products. One of the quality control methods is failure mode and effect analysis (FMEA). This study uses the FMEA to identify the causes of the defects and recommend the prevention methods to overcome the causes of the defects in an Indonesian paper mill. The risk priority number (RPN) is calculated by multiplying the severity, occurrence, and detection of the failures that have been determined. Unsymmetrical and tainted products are the most dominant defects in the paper mill. An inappropriate machine setting is the cause of unsymmetrical products with the highest RPN of 343 . The second highest RPN is problems with bleaching machines that caused tainted products with an RPN value of 216. This study offers suggestions to Indonesian paper mill to prevent and minimize defective products.
\end{abstract}

Keywords: quality control, defects, paper mill, FMEA, RPN

\begin{abstract}
Abstrak
Sistem pengendalian mutu yang baik sangat penting untuk diimplementasikan agar dapat meningkatkan produktivitas dan menekan jumlah produk cacat. Salah satu metode pengendalian mutu adalah failure mode and effect analysis (FMEA). Penelitian ini menggunakan FMEA untuk mengidentifikasi penyebabpenyebab dari produk cacat yang selanjutnya merekomendasikan metode penanggulangan dari penyebab produk cacat pada salah satu pabrik kertas di Indonesia. Risk priority number (RPN) dihitung dengan mengalikan severity, occurrence, dan detection dari kegagalan dalam proses yang telah diidentifikasi. Produk tidak simetris dan bernoda adalah jenis cacat produk yang paling dominan pada pabrik kertas ini. Ketidaksesuaian seting dari mesin adalah penyebab dari ukuran produk yang tidak simetris dengan nilai RPN tertinggi sebesar 343. Nilai RPN tertinggi kedua adalah masalah pada mesin pemutih yang menyebabkan noda pada produk, dengan nilai RPN sebesar 216. Penelitian ini memberikan saran pada pabrik kertas untuk mencegah dan menekan jumlah produk cacat.
\end{abstract}

Kata Kunci: pengendalian mutu, produk cacat, pabrik kertas, FMEA, RPN

\section{Introduction}

High-quality products are beneficial in terms of gaining trust from the customers in order to survive in the competition. Customer requirements should be guaranteed to ensure customer satisfaction (ISO, 2008). Companies must enhance their production process because it is the main factor in determining the quality of the products. Defective products may increase the cost and production time because quality, productivity, and cost are closely related (Mandavgade \& Jaju, 2009). A good quality control system is expected to increase the quality of the products by reducing the number of defects.

The current case study was conducted in a paper mill in Bogor, Indonesia to identify and minimize defective products using FMEA. This company produces a carbonless copy, laid watermark and embossed, printing and writing, 
diazo base, glassine, greaseproof, release base, security, and kraft paper. In this study, we evaluated the white paper for printing and writing with consideration it is the most used paper product. Controlling the quality of existing products can reduce the number of defective products.

The quality control system aims to fulfill customer satisfaction by delivering defect-free products at minimum cost. One of the tools that can be used is the implementation of FMEA. FMEA is a structured method that can effectively analyze and assess potential risks to improve a process (Xi \& Xu, 2002; Liu et al., 2016; Jia et al., 2017). It is a tool to analyze and discover all potential failures and the effects of failures that occur in the system to minimize them (Dudek-Burlikowska, 2011; Liu et al., 2018). The following sections explain the detailed use of this tool and its application in the case study.

\section{Methodology}

\section{Data Collection}

The case study was conducted in a paper mill in Bogor, Indonesia. Historical data of product defects from January 2019 until January 2020 were collected, as can be seen in Table 1. In addition, interviews were also done to identify the problems within the production process that might cause paper defects.

Table 1. Defective products data in January 2019 January 2020

\begin{tabular}{|c|c|c|c|}
\hline No & Month & $\begin{array}{l}\text { Product } \\
\text { Amount }\end{array}$ & Total Defects \\
\hline 1. & Jan 2019 & 209856736 & 6296 \\
\hline 2. & Feb 2019 & 198287049 & 5945 \\
\hline 3. & Mar 2019 & 208509683 & 6252 \\
\hline 4. & Apr 2019 & 208553393 & 6255 \\
\hline 5. & May 2019 & 209494322 & 6285 \\
\hline 6. & Jun 2019 & 208744946 & 6262 \\
\hline 7. & Jul 2019 & 208659030 & 6060 \\
\hline 8. & Aug 2019 & 197862714 & 5939 \\
\hline 9. & Sep 2019 & 199385245 & 5982 \\
\hline 10. & Oct 2019 & 200183746 & 6005 \\
\hline 11. & Nov 2019 & 207097258 & 6212 \\
\hline 12. & Dec 2019 & 208193701 & 6244 \\
\hline 13. & Jan 2020 & 208856392 & 6264 \\
\hline & TOTAL & 2673684215 & 80001 \\
\hline
\end{tabular}

\section{Quality Control}

Quality consists of product features to meet and satisfy the needs of the customers (Gasperz, 2003). Quality can be defined by either the manufacturers or the customers. Manufacturers determine quality by the specifications, while customers determine quality by their needs and desires. Quality control is a verification and maintenance system to maintain the desired level of product or process quality (Montgomery, 2009). The production process needs to be carefully planned with the proper use of equipment, ongoing inspection, and corrective actions when needed. Thus, quality control is not only about determining good and bad products.

\section{FMEA Procedures}

FMEA is usually carried out during the conceptual and initial design stages from the system to ensure that all possible failures have been considered and appropriate efforts to overcome them have been made to minimize all potential failures (Parsana \& Patel, 2014). The FMEA method starts by determining the potential failure and their effects, then the severity of each effect of potential failures are determined by giving rank from 1 (low risk) to 10 (maximum severity). After that, the potential causes of each potential failure can be identified, and their occurrence is determined by giving rank from 1 (rare) to 10 (very high) occurrence rate. The control methods are then identified to prevent potential causes of the failure by doing an inspection. After that, the detection value associated with the control methods is measured by giving rank from 1 (very effective) to 10 (very ineffective). Ultimately, the Risk Priority Number (RPN) is calculated by multiplying severity, occurrence, and detection. The problem with the highest value of RPN should be set as a priority to be solved first (Parsana \& Patel, 2014).

FMEA is an effective method to identify and eliminate or control the failure, minimizes the damage system and its users. It improves the accuracy of the estimated possibility of failure to be developed. By using FMEA, product reliability may increase and time to do the design will be reduced because the problems have been identified and fixed (Zhang \& Dong, 2018).

\section{Fault Tree Analysis}

Fault Tree Analysis (FTA) is a technique to classify the instrumental relationships leading to a specific failure mode. FTA is easier to understand because it is a graphical 
representation of the relationships between the failure modes (Whiteley et al., 2015). The interactions between failure modes can be seen from the simple representation. However, the FTA does not consider the dependencies between failure modes and it must be observed individually for each failure mode (Whiteley et al., 2015).

\section{Results and Discussion}

The stages of constructing FMEA in this case study are as follows.

1. Determination of Type of Potential Failures

Based on the interview and historical data, the types of failures with the most potential to occur during the production process in the paper mill are Unsymmetrical and Tainted products. The next step is to analyze how serious the effects of these failures.

2. Determination of Effects Caused by Failure The effects of the above failures are products are not in accordance with production standards and are not feasible to be produced further, products did not meet the specifications desired by the customer, defective products interfere the product function, and products are inappropriate to be packaged.

3. Determination of the Severity of Failure Effects (S)

The failures that occur during the production process are influenced by the main factors namely machine, people, methods, and materials. Thus, the failure effects are assessed based on these factors. From the interviews with the company, the value of the failure effect (severity) of the type of failure can be determined.

4. Determination of the Value of Failure Occurrence (O)

The value of the chance of the type of failure (occurrence) is determined based on the interviews with the company.

5. Identification of Failure Control Methods By considering the causes of failure, the control over the causes can be carried out by workers to minimize the risk of failure.

6. Determination of Failure Detection Value (D) The failure detection value is also calculated based on the interview with the company.

7. Calculation of the RPN value After the Severity (S), Occurrence (O), and Detection (D) values are obtained, the RPN value is calculated to determine priority for the corrective action recommendations. The FMEA with RPN value can be seen in Table 2.

From the calculation of the RPN, it can be seen the cause of the failure of the process resulting in defective products. The causes of defects are then sorted based on the highest RPN value as can be seen in Table 3. From the table, the highest RPN value for the type of defect Unsymmetrical is 343 with the cause of failure is inappropriate machine settings that cause the paper cannot be formed perfectly. Meanwhile, the second-highest RPN for the type of defect Tainted is 216 with the cause of failure is frequent problems in bleaching machines. Based on the evaluation, it can be concluded that these two causes of failures are the top priority for immediate repairs.

In addition to the FMEA analysis, the FTA method was also used to see the basic events (BE) that contribute to the defects. As can be seen in Figure 1, there are 12 basic events in total from the top 2 causes of defects, namely unsymmetrical size and tainted paper. The unsymmetrical size paper is caused by inappropriate machine settings, lack of maintenance, lack of discipline, reckless behavior of the operators, bad raw materials, and the SOP has not been implemented correctly. Meanwhile, the tainted paper is caused by bleaching machine problems, bad raw materials, SOP has not been implemented correctly, less systematic procedure, lack maintenance, and reckless behavior of the operators. Using the FTA, it is clear that the company needs to overcome the basic events in order to reduce the number of defects.

The limitation of this study is that we could only give suggestions to the company since the authors had no authority to enforce the implementation of the suggestions. Future studies conducted in the paper mill in Bogor are strongly encouraged to evaluate the impact of the implementation of the suggestions in this study.

\section{Conclusion}

The objective of this study is to identify and analyze defects in the white paper using failure mode and effect analysis (FMEA). Our results show that the defects in the products are mostly unsymmetrical shapes and tainted products. 
Table 2. PFMEA with RPN value

\begin{tabular}{|c|c|c|c|c|c|c|c|c|}
\hline Failure & Effects & Factor & $\mathbf{S}$ & Causes & 0 & Countermeasure & D & RPN \\
\hline \multirow[t]{6}{*}{ Unsymmetrical } & \multirow{6}{*}{$\begin{array}{l}\text { Products did } \\
\text { not meet } \\
\text { production } \\
\text { standard, did } \\
\text { not meet } \\
\text { customers' } \\
\text { specifications, } \\
\text { interfere with } \\
\text { product } \\
\text { function, } \\
\text { inappropriate } \\
\text { to be sold }\end{array}$} & \multirow[t]{2}{*}{ Machine } & 7 & $\begin{array}{l}\text { Inappropriate } \\
\text { machine } \\
\text { settings } \\
\end{array}$ & 7 & $\begin{array}{lr}\text { Check the } \\
\text { machine before } \\
\text { using }\end{array}$ & 7 & 343 \\
\hline & & & 5 & $\begin{array}{l}\text { Lack of } \\
\text { maintenance }\end{array}$ & 6 & $\begin{array}{ll}\text { SOP } & \text { for } \\
\text { maintenance } & \end{array}$ & 6 & 180 \\
\hline & & \multirow[t]{2}{*}{ Human } & 4 & $\begin{array}{ll}\text { Lack of } \\
\text { discipline }\end{array}$ & 6 & $\begin{array}{l}\text { Stricter } \\
\text { supervision }\end{array}$ & 5 & 120 \\
\hline & & & 5 & Reckless & 5 & $\begin{array}{l}\text { Add operators for } \\
\text { certain activities }\end{array}$ & 4 & 100 \\
\hline & & Methods & 4 & $\begin{array}{l}\text { SOP is not } \\
\text { implemented } \\
\text { correctly }\end{array}$ & 5 & $\begin{array}{l}\text { Develop more } \\
\text { systematic SOP }\end{array}$ & 4 & 80 \\
\hline & & Materials & 5 & $\begin{array}{l}\text { Bad raw } \\
\text { materials }\end{array}$ & 5 & $\begin{array}{l}\text { Establish quality } \\
\text { standard }\end{array}$ & 4 & 100 \\
\hline \multirow[t]{7}{*}{ Tainted } & \multirow{7}{*}{$\begin{array}{l}\text { Products did } \\
\text { not meet } \\
\text { production } \\
\text { standard, did } \\
\text { not meet } \\
\text { customers' } \\
\text { specifications, } \\
\text { interfere with } \\
\text { product } \\
\text { function, } \\
\text { inappropriate } \\
\text { to be sold }\end{array}$} & \multirow[t]{2}{*}{ Machine } & 6 & $\begin{array}{l}\text { Problems } \\
\text { with } \\
\text { bleaching } \\
\text { machine }\end{array}$ & 6 & $\begin{array}{l}\text { Replace certain } \\
\text { components in } \\
\text { the machine }\end{array}$ & 6 & 216 \\
\hline & & & 4 & $\begin{array}{l}\text { Lack of } \\
\text { maintenance } \\
\text { on bleaching } \\
\text { machine }\end{array}$ & 5 & $\begin{array}{l}\text { Perform routine } \\
\text { checks }\end{array}$ & 5 & 100 \\
\hline & & \multirow[t]{2}{*}{ Human } & 4 & $\begin{array}{l}\text { Not } \\
\text { implement } \\
\text { SOP } \\
\text { correctly }\end{array}$ & 3 & $\begin{array}{l}\text { Briefing before } \\
\text { each shift change }\end{array}$ & 4 & 64 \\
\hline & & & 3 & Reckless & 3 & $\begin{array}{ll}\text { Monitor } & \text { and } \\
\text { supervise } & \\
\text { employee } & \end{array}$ & 3 & 27 \\
\hline & & \multirow[t]{2}{*}{ Methods } & 5 & $\begin{array}{l}\text { SOP is not } \\
\text { implemented } \\
\text { correctly }\end{array}$ & 6 & $\begin{array}{ll}\text { Develop more } \\
\text { systematic } \\
\text { methods }\end{array}$ & 5 & 150 \\
\hline & & & 4 & $\begin{array}{l}\text { Less } \\
\text { systematic }\end{array}$ & 6 & $\begin{array}{l}\text { Develop SOP in } \\
\text { applying correct } \\
\text { methods }\end{array}$ & 5 & 120 \\
\hline & & Materials & 5 & $\begin{array}{l}\text { Bad raw } \\
\text { materials }\end{array}$ & 6 & $\begin{array}{l}\text { Establish quality } \\
\text { standard }\end{array}$ & 6 & 180 \\
\hline
\end{tabular}

Table 3. Sequence of process failure based on RPN

\begin{tabular}{|c|c|c|c|}
\hline Failure Type & Causes of Failure & Countermeasure & RPN \\
\hline Unsymmetrical & Inappropriate machine settings & Check the machine before using & 343 \\
\hline Tainted & $\begin{array}{c}\text { Problems with bleaching } \\
\text { machine }\end{array}$ & $\begin{array}{l}\text { Replace certain components on the } \\
\text { bleaching machine }\end{array}$ & 216 \\
\hline Unsymmetrical & Lack of maintenance & Develop SOPs for machine maintenance & 180 \\
\hline Tainted & Bad raw materials & $\begin{array}{l}\text { Establish quality standards and take } \\
\text { samples from third parties for quality } \\
\text { testing }\end{array}$ & 180 \\
\hline Tainted & $\begin{array}{l}\text { SOP is not implemented } \\
\text { correctly }\end{array}$ & Develop more systematic methods & 150 \\
\hline Unsymmetrical & Lack of discipline & $\begin{array}{c}\text { Stricter supervision and make applicable } \\
\text { regulations }\end{array}$ & 120 \\
\hline Tainted & Less systematic & Develop SOP in applying work methods & 120 \\
\hline Unsymmetrical & Reckless & $\begin{array}{l}\text { Add operators to certain production } \\
\text { activities }\end{array}$ & 100 \\
\hline Unsymmetrical & Bad raw materials & $\begin{array}{c}\text { Establish quality standards and take } \\
\text { samples from third parties for quality } \\
\text { testing }\end{array}$ & 100 \\
\hline
\end{tabular}


DOI: https://doi.org/10.26593/jrsi.v9i3.4059.171-176

Table 3. Sequence of process failure based on RPN (cont.)

\begin{tabular}{|c|c|c|c|}
\hline Failure Type & Causes of Failure & Countermeasure & RPN \\
\hline Tainted & $\begin{array}{c}\text { Lack of maintenance on } \\
\text { bleaching machines }\end{array}$ & Perform routine checks & 100 \\
\hline Unsymmetrical & $\begin{array}{c}\text { SOP has not been } \\
\text { implemented correctly }\end{array}$ & Develop more systematic work methods & 80 \\
\hline Tainted & Not implement SOP correctly & $\begin{array}{c}\text { Conduct briefings at each change of work } \\
\text { shift }\end{array}$ & 64 \\
\hline Tainted & Reckless & Monitor and supervise employee & 27 \\
\hline
\end{tabular}

In order to minimize these defects, the company needs to improve its production process by:enforcing the SOP, training the operators, using better quality of raw materials, and conducting regular maintenance on the machines. A quality control system using FMEA can be used to improve the programs and policies within the company to increase productivity. The company must review and establish the appropriate procedures to reduce the number of defective products.

\section{References}

Dudek-Burlikowska, M. (2011). Application of FMEA method in enterprise focused on quality. Journal of Achievements in Materials and Manufacturing Engineering, 45(1), 89-102.

Gaspersz, V. (2003). Total Quality Management (TQM). Jakarta: PT. Gramedia Pustaka Utama.

ISO. ISO 9001. (2008). Quality Management Systems. Requirements.

Jia, H., Li, Z., \& Liu, H.C. (2017). New approach for failure mode and effect analysis using linguistic distribution assessments and TODIM method. Reliability Engineering and System Safety, 167, 302-309.

Liu, H.C., You, J.X., Li, P., \& Su, Q. (2016). Failure mode and effect analysis under uncertainty: An integrated multiple criteria decision making approach. IEEE Transactions on Reliability, 65(3), 13801392.

Liu, H.C., You, X.Y., Tsung, F., \& Ji, P. (2018). An improved approach for failure mode and effect analysis involving large group of experts: An application to the healthcare field. Quality Engineering, 30(4), 762-775.
Lo, H.W., Liou, J.J.H., Huang, C.N., \& Chuang, Y.C. (2018). A novel failure mode and effect analysis model for machine tool risk analysis. Reliability Engineering and System Safety, 183, 173-183.

Mandavgade, N.K., \& Jaju, S.B. (2009). Optimization of cost by using $7 \mathrm{QC}$ tools. International Journal of Engineering Studies, 1, 149-160.

Mhetre, R. S., \& Dhake, R. J. (2012). Using failure mode effect analysis in a precision sheet metal parts manufacturing company. International Journal of Applied Science and Engineering Research, 1(2), 302-311.

Montgomery, D. C. (2009). Introduction to Statistical Quality Control. Danvers, MA: John Wiley and Sons, Inc.

Parsana, T. S., \& Patel, M. T. (2014). A case study: A process FMEA tool to enhance quality and efficiency of manufacturing industry. Bonfring International Journal of Industrial Engineering and Management Science, 45(3), 145-148.

Whiteley, M., Dunnet, S., \& Jackson, L. (2015). Failure mode and effect analysis, and fault tree analysis of polymer electrolyte membrane fuel cells. International Journal of Hydrogen Energy, 41(2), 1187-1202.

Xi, L.F. \& Xu, G. (2002). The application of FMEA in process management. Journal of Industrial Engineering and Management, 1, 37-39.

Zhang, H., Dong, Y., Palomares-Carrascosa, I., \& Zhou, H. (2019). Failure mode and effect analysis in linguistic context: A consensusbased multiattribute group decision-making approach. IEEE Transactions on Reliability, 68(2), 566-582. 


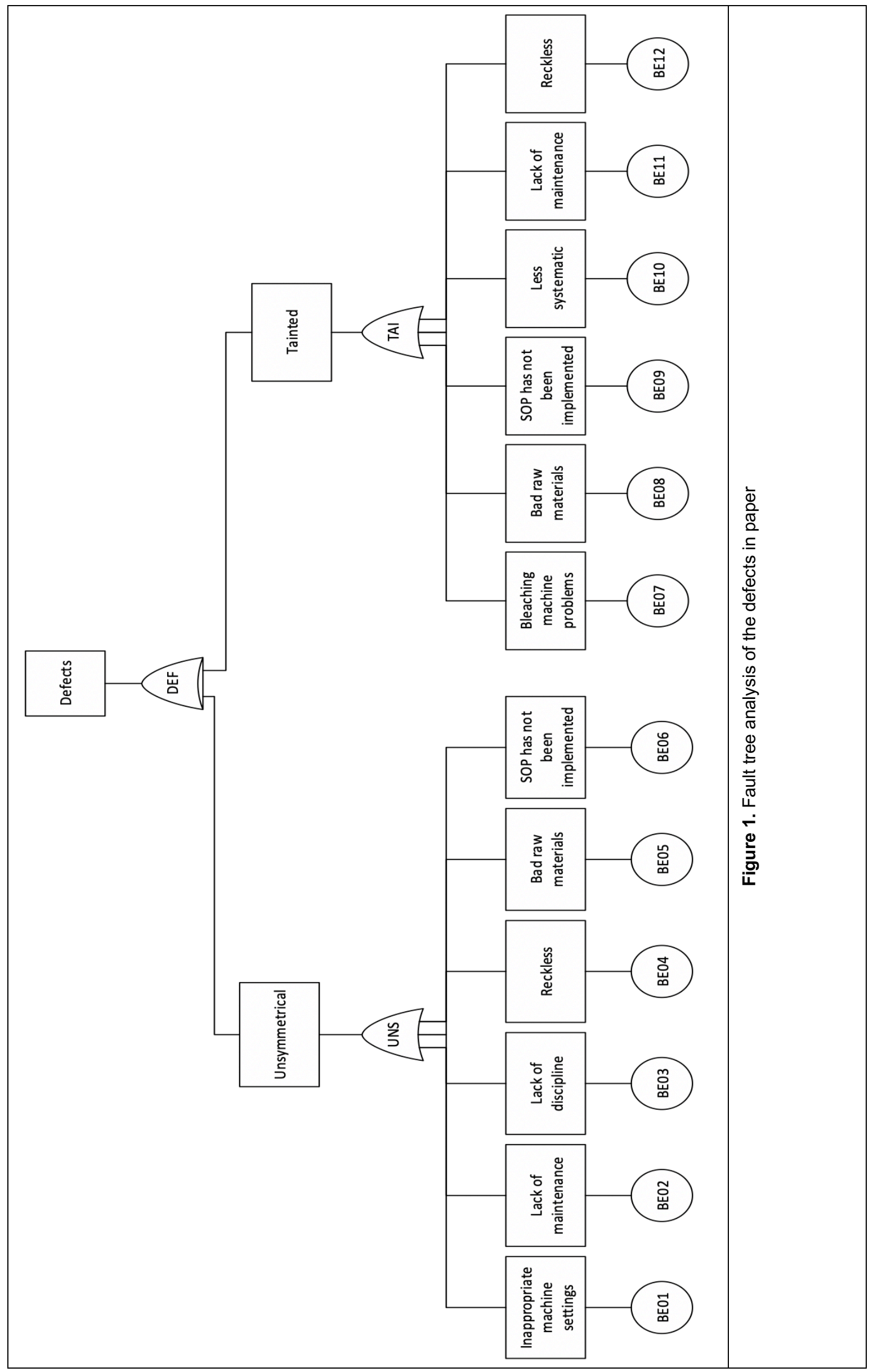

